\title{
A Proposed Model for Accounting Treatment of Ijarah
}

\author{
Muhannad A. Atmeh ${ }^{1} \&$ Jamal Abu Serdaneh ${ }^{2}$ \\ ${ }^{1}$ TAG Graduate School of Business Administration, German Jordanian University, Amman, Jordan \\ ${ }^{2}$ Faculty of Business Studies, Arab Open University - Jordan Branch, Amman, Jordan \\ Correspondence: Muhannad A. Atmeh, TAG Graduate School of Business Administration, Mecca Street, P.O. \\ Box 921951, Amman 11192, Jordan. Tel: 962-7-950-1220. E-mail: muhannad.atmeh@gju.edu.jo
}

Received: May 22, 2012 Accepted: June 20, 2012 Online Published: September 16, 2012

doi:10.5539/ijbm.v7n18p49 URL: http://dx.doi.org/10.5539/ijbm.v7n18p49

\begin{abstract}
Islamic banks use finance leases as a mode of financing, after incorporating major alterations in the structure of the contract in order to meet Shariah principles. In this case, the contract is called 'Ijarah Muntahia Bittamleek'. As different structures might lead to different accounting results, the Accounting and Auditing Organization for Islamic Financial Institutions (AAOIFI) issued Financial Accounting Standards to tackle the accounting treatment for such transactions. The paper criticised the accounting treatment offered by AAOIFI for violating the matching principle and lacking faithful representation. Suggested amendments for accounting treatments are also proposed.
\end{abstract}

Keywords: Ijarah, lease, Islamic accounting, Accounting and Auditing Organization for Islamic Financial Institutions (AAOIFI), financial reporting

\section{Introduction}

Ijarah, also referred to as 'Islamic lease', is a contract where one party transfers the usufruct (Note 1) of an item to another party for a specified period, in exchange for a specified consideration (Asian-Oceanian Standard-Setters Group [AOSSG], 2010). Hence, in an "Ijarah" contract the lessor retains the ownership of the leased asset while transferring the right to use the asset, or usufruct, to another party as the lessee. All liabilities and risks pertaining to the leased asset are to be borne by the lessor. This includes obligations to restore any impairment and damage to the leased asset which are not due to the lessee's misconduct or negligence (Fatima, 2006).

The rules of Ijarah, in the sense of leasing, are very similar to the rules of sale, as in both cases something is transferred to another person for a valuable consideration. The only difference between Ijarah and sale is that in the case of sale the legal title of the property is transferred to the purchaser, while in Ijarah, the legal title of the property remains in the ownership of the transferor, but only the right to use the property, is transferred to the lessee (Usmani, 2003). Therefore, Ijarah basically could be viewed as an operating activity rather than financing activity. However, this transaction has also been used in the Western countries as financing products. This is mainly due to some tax concessions embedded in this form of transaction. For example, some financial institutions buy and lease some equipment to their customers, instead of giving a direct loan to the customer to finance the purchasing of the equipment. While fixing the rent (Note 2) of these equipments, the financial institutions calculate the total cost they have incurred in the purchase of these assets and add the stipulated interest they could have claimed on such an amount during the lease period. Then, the total amount calculated is divided among the lease period.

From the conventional accounting point of view, accounting standard setters differentiate between two types of leases: a finance lease where the lessor transfers substantially all the risks and rewards incidental to ownership, and an operating lease where the lessor does not substantially transfer all the risks and rewards incidental to ownership (International Accounting Standard (IAS) 17). Accordingly, the accounting treatment of leases differs, depending on the classification of the lease; finance lease or operating lease (Note 3).

In the case of finance leases, the transaction is construed as a contract that represents, in substance, a purchase or sale of an underlying asset, instead of a lease. Hence, the revenue is generated from sales plus the interest that resulted from deferring the receipt of the sale price (lease installments). 
It is obvious from the above that the traditional finance lease contradicts with Shariah principles as interest element is embedded in this type of contract. However, the Islamic banks use finance leases as a mode of financing but after incorporating major alterations in the structure of the contract in order to meet Shariah principles. In this case, the contract is called 'Ijarah Muntahia Bittamleek', i.e., Ijarah contract that ends up with the transfer of ownership of leased assets to the lessee (AAIOIF, 2008, P. 277). As different structures might lead to different accounting results, AAOIFI (Note 4) issued the Financial Accounting Standards (FAS) 8; Ijarah and Ijarah Muntahia Bittamleek to tackle the accounting treatment for such type of transactions.

This paper investigates the differences between the traditional finance lease and Ijarah Muntahia Bittamleek from two perspectives: the structure and conditions of the contract itself and the accounting treatment.

The paper proceeds as follows. Section 2 demonstrates the characteristics of Ijarah Muntahia Bittamleek according to Shariah principles, and a comparison with the traditional finance lease is also provided, Section 3 examines the accounting treatment for leases according to AAOIFI and for both sides; the lessee and the lessor. Afterwards, a proposed accounting model is introduced; Section 4 presents the conclusions and remarks.

\section{Characteristics of Ijarah Muntahia Bittamleek}

Many of the Islamic banks have adopted leasing as a financing method to avoid long term lending on a basis of interest. This type of lease is known, in conventional banking, as a finance lease, to distinguish it from the operating lease (Note 5). However, and in order comply with Shariah rules, several conditions should be met to ensure the difference between leasing and an interest bearing loan. The conditions that are unique to Ijarah Muntahia Bittamleek and affect the accounting treatments are as follows: (Usmani, 2003)

\subsection{Lessor Obligations}

Lessor obligations are considered as a major difference between the traditional finance lease and Ijarah Muntahia Bittamleek. In finance lease, it is assumed that the lessor transfers substantially all the risks and rewards incidental to ownership, which is not the case in Ijarah Muntahia Bittamleek and for the following reasons:

In Ijarah Muntahia Bittamleek, the lessor has an obligation to maintain the asset and its usufruct for the lessee's use. This would include responsibility for major maintenance, major repair costs, and risks associated with permanent impairment; for example, a house under Ijarah being destroyed in an earthquake (AOSSG, 2010). Additionally, it is not permissible to stipulate in the contract that the major maintenance and repair costs of the leased asset are to be carried out by the lessee as this would lead to the lessee paying a rent that includes an unknown element (AAOIFI, 2008, P. 269).

Furthermore, and in case of impairment of leased asset, the lessor must either offer the client a similar asset to use for the remainder of the contract or refund part of the lease rental, unless the impairment was caused by misuse or negligence on the part of the lessee. In other words, as the corpus of the leased property remains in the ownership of the lessor, all the liabilities emerging from the ownership shall be borne by the lessor, while the liabilities referable to the use of property shall be borne by the lessee (Usmani, 2003).

The lessor obligations mentioned above could be regarded as evidence that the lessor retaining "exposure to significant risks and benefits associated with the underlying asset"(AOSSG, 2010). Therefore, AAOIFI accounting standards treated Ijarah Muntahia Bittamleek as an operating lease.

\subsection{Transferring the Leased Asset to the Lessee}

In the traditional finance lease, the leased asset is transferred generally to the lessee at the end of the lease, either free of any charge or at a nominal token price. In some contracts, this condition is expressed explicitly, or it could be understood implicitly between the parties that the title of the asset will be passed on to the lessee at the end of the lease term (Usmani, 2003). However, and from Shariah point of view, this arrangement of conveying ownership is prohibited as two agreements, e.g. lease and sale, cannot take place within one contract. It is a well settled rule of Islamic jurisprudence that, in specific types of transactions, one transaction cannot be tied up with another transaction so as to make the former a precondition for the other. If lease and sale are included in one contract, this transaction can be viewed as a deferred sale with a deferred payment, which is not acceptable in Shariaeh principles. AAOIFI requires Ijarah Muntahia Bittamleek to be accounted for as separate transactions of an operating lease followed by a disposal. AAOIFI recommends the following four ways to transfer ownership of an asset in Ijarah Muntahia Bittamleek:

(a) Transfer through gift;

(b) Transfer through sale for a token consideration or other amount as specified in the lease;

(c) Transfer through sale prior to the end of the lease term for a price equivalent to the remaining Ijarah 
installments; and

(d) Transfer through gradual sale of the leased asset

It should be noted that Ijarah itself should not contain a condition of gift or sale at the end of the lease period. However, the lessor may enter into a separate unilateral promise (option) to sell the leased asset to the lessee at the end of the lease period at a specified mutually acceptable price if the lessee has paid all the amounts of rentals.

Similarly, it is also allowed that, instead of sale, the lessor signs a separate promise to gift the leased asset to the lessee at the end of the lease period, subject to his payment of all amounts of rent. It is worth mentioning that the promise creates a legal obligation, or at least a constructive obligation, on the promisor (AOSSG, 2010).

For financial reporting, and according to AAOIFI, the Ijarah and the transfer of ownership are accounted for as separate transactions, and are not considered as linked transactions. Hence, Ijarah Muntahia Bittamleek is not treated as sale or purchase of the underlying asset, despite the arrangement to transfer ownership by, or at the end, of the lease.

\section{Accounting Treatment}

It is evident that the traditional finance lease and Ijarah Muntahia Bittamleek have dissimilar structures. Accordingly, the accounting treatment for leases differs between International Financial Reporting Standards (IFRS) and AAIOFI standards. In the traditional finance lease, the leased asset is recognized in the books of the lessee plus a corresponding liability (lease payments), while the lessor derecognizes the leased asset from his books and recognizes receivables asset (lease payments to be received). This is because all the risks and rewards incidental to legal ownership are assumed to be transferred by the lessor to the lessee (Uddin, 2012).

In contrary, the leased assets in Ijarah Muntahia Bittamleek are recognized in the books of the lessor and not capitalized in the lessee books. Consequently, the leased assets are depreciated in the books of the lessor. In other words, all Ijarah contracts are treated as operating leases under the AAOIFA standards.

This paper does not aim mainly to compare the accounting treatment for leases among different financial reporting frameworks (For more insights see Uddin, 2012; ACCA \& KPMG, 2010; AOSSG, 2011; Rosly, 2010). Instead, it examines the AAOIFI accounting model for Ijarah Muntahia Bittamleek through gift when the Ijarah term is substantially shorter than the useful life of the leased asset. Under this case, implementing AAOIFI treatment may result in misleading financial statements and may not reflect the economic substance of Ijarah contract.

Table 1. Key differences of accounting treatment between IFRS and AAOIFI

\begin{tabular}{|c|c|c|}
\hline Item & IFRS (IAS 17) & AAOIFI (FAS 8) \\
\hline $\begin{array}{l}\text { Classification } \\
\text { of leases }\end{array}$ & $\begin{array}{l}\text { Lease is classified as a finance lease if it transfers } \\
\text { substantially all the risks and rewards incidental to } \\
\text { ownership. A lease is classified as an operating } \\
\text { lease if it does not transfer substantially all the risks } \\
\text { and rewards incidental to ownership. }\end{array}$ & $\begin{array}{l}\text { All leases should be classified as an } \\
\text { operating lease. } \\
\text { Ijarah ending with a transfer of } \\
\text { ownership should be treated as two } \\
\text { separate transactions of operating lease } \\
\text { and sale, and not as a finance lease. }\end{array}$ \\
\hline $\begin{array}{l}\text { Leases in the } \\
\text { financial } \\
\text { statements of } \\
\text { lessees }\end{array}$ & $\begin{array}{l}\text { At the commencement of the lease term, lessees } \\
\text { shall recognize finance leases as assets and } \\
\text { liabilities in their statements of financial position at } \\
\text { amounts equal to the fair value of the leased } \\
\text { property or, if lower, the present value of the } \\
\text { minimum lease payments, each determined at the } \\
\text { inception of the lease. The discount rate to be used } \\
\text { in calculating the present value of the minimum } \\
\text { lease payments is the interest rate implicit in the } \\
\text { lease, if this is practicable to determine; if not, the } \\
\text { lessee's incremental borrowing rate shall be used. } \\
\text { Any initial direct costs of the lessee are added to the } \\
\text { amount recognized as an asset }\end{array}$ & $\begin{array}{l}\text { In case of ljarah ending with a transfer } \\
\text { of ownership, the lessee would } \\
\text { recognize lease payments as expenses } \\
\text { throughout the lease term. } \\
\text { When the asset is transferred to the } \\
\text { lessee, the lessee would recognise the } \\
\text { asset acquired }\end{array}$ \\
\hline
\end{tabular}


Lessors shall recognize assets held under a finance lease in their statements of financial position and Leases in the present them as a receivable at an amount equal to financial the net investment in the lease

statements of lessors
In case of Ijarah ending with a transfer of ownership, the lessor would present an asset in its statement of financial position, and recognize lease installments as revenue throughout the lease term.

When the asset is transferred to the lessee, the lessor may recognise a gain or loss on disposal.

\subsection{Ijarah Muntahia Bittamleek through Gift in the Financial Statements of Lessees (Case of Ijarah Term is Substantially Shorter than the Useful Life of the Leased Asset)}

According to AAOIFI, FAS 8, the Ijarah installments should be allocated over the financial periods of the lease term and recognized as an Ijarah expense. At the end of Ijarah term, and when legal title in the leased asset passes to the lessee as a gift, the leased asset shall be recognized in the lessee's books and measured at its cash equivalent value at that time, and a corresponding credit is made to stockholders equity (i.e., retained earnings) (AAOIFI, 2008, P. 256).

It is clear from the above that Ijarah installments are recognized in full as expenses throughout the Ijarah term. However, when Ijarah term is substantially shorter than the useful life (Note 6) of the leased asset, the benefits from the leased asset are received during a longer period than Ijarah term, i.e., the useful life of the asset. Thus, the Ijarah expenses are overstated during the Ijarah term, and the matching principle is violated in this mechanism. This dilemma evolved from considering all payments as rent, although it is actually part of the price. Abu Ghuddah (2007) stated that if Ijarah contract is rescinded in any stage, the Ijarah rents paid by the lessee should be divided into two items: a consideration for usufruct and a consideration for ownership. The second item should be returned to the lessee when the contract is rescinded, otherwise it would be considered illegal.

AAOIFI recognized this concept when Ijarah Muntahia Bittamleek through gift is rescinded due to permanent impairment of the leased assets and offered the following treatment for the lessee in this event:

"if the leased assets are permanently impaired before the legal title passes to the lessee for no consideration and the impairment is not the result of the lessee's actions or omission, and the Ijarah installments already paid exceed the fair rental amount, then the difference between the two amounts ( namely what the lessee has paid towards the purchase of the asset and its fair rental value) shall be recognized as a receivable due from the lessor and credited to the income statement" (AAOIFI, 2008, P. 256)

And for the lessor books, the difference between the two amounts shall be recognized as a liability and charged to the income statement.

It is evident that the lessee may pay more than the fair rental value for the sake of the ownership at the end of the Ijarah term. Moreover, if ownership is deemed unattainable in any stage of Ijarah, the lessee is entitled to the consideration paid for ownership. Hence, the amounts that exceed the fair rental value are qualified to be recognized as asset in the lessee books since they represent a probable future economic value. This value will end up in ownership of fixed assets or receivables due from the lessor.

AAOIFI ignores the recognition of this asset throughout the Ijarah term and requires expensing of the full rental amount. However, when part of the rental amounts result in a fixed asset (the legal title of the leased asset passes to the lessee at the end of the Ijarah term), or in receivable (the Ijarah contract rescinded before the end of Ijarah term), AAOIFI offers two different treatments as mentioned previously. The first treatment is to increase the stockholders equity (i.e. retained earnings), in the case of a fixed asset, and the second treatment is to increase the income, in the case of receivable. Although AAOIFI doesn't provide any justification for using two different methods (Note 7), both of the methods violate the matching principle and lack faithful representation.

\subsubsection{Suggested Amendments}

It is presumably known, at the inception of Ijarah contract, whether or not part of the rental payments is considered as a consideration for ownership. Hence, this part should be recognized as asset, at each payment, rather than expense. This part can be determined as the difference between the rental payments (installments) and the fair value of rent. At the end of Ijarah term, the balance of this asset will be replaced by the leased asset. Or if the Ijarah contract is rescinded, the balance of this asset will be replaced by receivables due from lessor. 
This approach meets the matching principle as part of the rental payment which will participate in acquiring the leased asset or receivables is deferred and recognized as asset. Additionally; it achieves faithful representation as the assets presented in the balance sheet reflect the future economic benefits acquired by the lessee.

\subsubsection{Example}

Let us assume $\mathrm{ABC}$ Airlines (ABC) enters into an Ijarah contract for an aircraft from XYZ Leasing co. (XYZ). The aircraft has an expected useful life of 15 years with no residual value and XYZ's net investment in the aircraft (current cash price) is 90,000,000 Currency Unit (C.U).

The Ijarah arrangement is for 10 years, and Ijarah installments are 13,500,000 C.U per year and are made at the end of the year (yearly installment is calculated by dividing the price of the asset over the Ijarah term plus $5 \%$ of the price as a flat rate return). The legal title of the aircraft will be transferred to ABC for no consideration (gift) upon the settlements of all Ijarah installments.

For the sake of simplicity we assume that the fair rental value (Note 8) equals the depreciation of the asset plus the required return for XYZ. The yearly depreciation of the asset, using the straight line method, is $6,000,000$ C.U. and the yearly required return (5\% of the principle amount) is 4,500,000 C.U. Hence, the yearly fair rental value is $10,500,000$ C.U. The difference between the yearly installment and the yearly fair rental value is $3,000,000$ C.U. (ownership consideration). We assume that the fair value of the asset at the end of Ijarah term equals its book value.

According to AAOIFI, FAS 8, XYZ should recognize 13,500,000 C.U. as a yearly Ijarah expenses throughout the Ijarah term. At the end of Ijarah term, the end of tenth year, the legal title passes to XYZ and consequently, $\mathrm{XYZ}$ recognizes the asset at its fair value at that time which is assumed to be 30,000,000 C.U., and a corresponding credit is made to retained earnings.

According to the suggested amendment, XYZ recognizes 10,500,000 C.U. as a yearly Ijarah expenses and $3,000,000$ C.U. as an intangible asset (Note 9) throughout the Ijarah term. At the end of Ijarah term, the end of tenth year, the legal title passes to $\mathrm{XYZ}$ and consequently, $\mathrm{XYZ}$ reclassifies the intangible asset into a fixed asset (Note 10). The balance of the asset at that time equals 30,000,000 C.U.; this amount will be depreciated in the coming five years.

To sum up, in the amended treatment the installments paid for Ijarah are recognized as expenses through the useful life of the asset rather than the Ijarah term. This is achieved by separating the amount related to ownership and recording it as an asset. Eventually, and after the transfer of ownership, this asset is depreciated over the remaining useful life of the transferred asset. Hence, the matching principle and faithful presentation are met.

On the other hand, AAOIFI approach in considering the transferred asset as a gift from the lessor to the lessee is under question. Atmeh and Ramadan (2012) suggest that it is not appropriate to use donation (gift) contracts in conducting business with a commercial substance (Note 11). However, the suggested approach can provide a more suitable interpretation for transferring the leased asset to the lessee. If the rental installments are more than the fair rental value of the asset, then the lessor is liable to the lessee for the difference. This liability accumulates and extends by passing of time while the lessor owns the asset, and settled when the asset is transferred to the lessee at the end of Ijarah term. Hence, it can be perceived that the lessor gives up the leased asset to the lessee, not as a gift, but in lieu of settlement of his liability towards the lessee. From the lessee side, the same argument is valid. The lessee has a right to receive the difference between the rental installments and the fair rental value. At the end of Ijarah term, the lessee gives up this right by owning the leased asset. The suggested model reflects this perception in the accounting books. In the lessee books, the difference between the rental installments and the fair rental value is recognized as asset, and when the legal title passes to the lessee, this asset is replaced by the leased asset and not considered as a gift (no gain is recognized).

\subsection{Ijarah Muntahia Bittamleek through Gift in the Financial Statements of Lessors (Case of Ijarah Term is Substantially Shorter than the Useful Life of the Leased Asset)}

According to AAOIFI, FAS 8, assets acquired by the lesssor for Ijarah shall be recognized upon acquisition at historical cost and shall be depreciated without subtracting a residual value since these assets will be transferred to the lessee as a gift. The book value of the leased assets shall be presented in the lessor's balance sheet under Ijarah Muntahia Bittamleek Assets. Ijarah revenue shall be presented in the lessor's income statement and revenue shall be allocated proportionately to the financial periods in the lease term (AAOIFI, 2008, P. 250).

In examining this treatment two major points are noticed. First, the Ijarah installments are usually higher than the fair rental value of the leased asset. Secondly, the depreciation is allocated over the lease term which is shorter than the useful life of the asset. For the first point, the difference between the two amounts (namely what the 
lessee has paid towards the purchase of the asset and its fair rental value) comprises a contingent liability towards the lessor. AAOIFI disregards recording this liability through the ijrah term. However, when this amount is deemed due, the lessor charges it totally to the income statement at that date. For the second point, the leased asset is understated (depreciation expense is overstated) in the financial statements of the lessor as the asset is depreciated over a shorter time than the useful life of the asset. This is because the asset will be transferred to the lessee as a gift at the end of Ijarah term. Therefore, the asset must be fully depreciated at that time. Apparently, and similar to the lessee financial reporting, this treatment violate the matching principle and lacks faithful representation.

\subsubsection{Suggested Amendments}

It is presumably known, at the inception of Ijarah contract, whether or not part of the rental payments is considered as a consideration for ownership. Hence, this part should be recognized as a liability, at each payment, rather than revenue. This part can be determined as the difference between the rental payments and the fair value of rent. On the other hand, depreciation expense should be determined according to the useful life of the asset rather than the lease term. Allocating depreciation over the useful life of the asset may enhance the perception that the lessor is the real owner (in substance) of the asset, which may help in differentiating between the Ijarah and traditional lease. At the end of Ijarah term, and when the legal title passes to the lessee, the lessor closes two accounts: the outstanding balance of the contingent liability and the book value of the leased asset (Note 12). Transferring the legal title to the lessee can be interpreted as the lessor selling the asset in exchange for discharging him from the contingent liability, rather than the asset is being donated as a gift. This approach meets the matching principle and achieves faithful representation as the assets and liabilities presented in the balance sheet reflect the economic substance of the transactions.

\subsubsection{Example}

Referring to the previous example, and according to FAS 8 , ABC should recognize 13,500,000 as yearly Ijarah revenue and 9,000,000 as a yearly depreciation expense throughout the Ijarah term. At the end of Ijarah term, the end of tenth year, the legal title passes to XYZ, but ABC don't record any entry as the asset is fully depreciated and its book value is zero.

According to the suggested amendment, $\mathrm{ABC}$ recognizes 10,500,000 C.U as yearly Ijarah revenue and 3,000,000 C.U as a liability throughout the Ijarah term. At the end of Ijarah term, the end of tenth year, the balance of the liability is $30,000,000$ C.U and also the book value of the leased asset is $30,000,000$ C.U. When the legal title passes to $\mathrm{XYZ}, \mathrm{ABC}$ closes the balance of the liability and the related balances of the leased asset without recognizing any gains or losses.

In both treatments, the yearly net income equals 4,500,000 C.U but the revenues and expenses are overstated according to AAOFIF treatment. Additionally, if the contract is rescinded and the lessor deemed to be liable for the difference between the installment received and the fair rental value, AAOFIF treatment recognizes this amount as a loss while in the suggested treatment no losses should be recorded. This is because a contingent liability is recorded yearly to meet such case.

\section{Conclusion}

Ijarah Muntahia Bittamleek is distinguished from traditional finance lease in two aspects: the structure of the contract itself and, consequently, the accounting treatment. In Ijarah Muntahia Bittamleek, the lessor retains substantially all the risks and rewards incidental to ownership, which is not the case in the traditional finance lease. Hence, in Ijarah Muntahia Bittamleek, the leased asset is presented in the balance sheet of the lessor (AAIOFI), while in the traditional lease; the leased asset is presented in the balance sheet of the lessee. Moreover, the Ijarah installments shall be allocated over the financial periods of the lease term and shall be recognized as Ijarah expense (revenue) in the lessee (lessor) books.

The accounting treatment provided by AAIOFI may result in distorting the financial reporting for both the lessee and the lessor, especially when Ijarah term is substantially shorter than the useful life of the leased asset. Considering the full Ijarah installments as revenue or expenses may not reflect the substance of the contract as part of the installments comprises the price of the leased asset. The paper proposed that the installments be split into two components: the fair rental value and the price. Thus, the accounting recording for the lessee (lessor) will recognize asset (liability) in addition to the expense (revenue). The proposed approach mirrors the Ijarah contract specifications in the accounting books and achieves the matching principle and fair presentations. 


\section{References}

Abu Ghuddah, A. (2007). Ijarah (Lease). Dallah Al-Baraka Group, Department of Research \& Development. Retrieved from http://www.albaraka.com/media/pdf/Research-Studies/RSIJ-200706201-EN.pdf

ACCA., \& KPMG. (2010). AccountAncy futures: Harmonising financial reporting of Islamic finance. Retrieved from http://www2.accaglobal.com/pubs/general/activities/library/financial_reporting/other/tech-af-hfrif.pdf

Accounting and Auditing Organization for Islamic Financial Institutions (AAOIFI). (2008). Accounting, Auditing and Governance Standards for Islamic Financial Institutions. AAOIFI, Manamah.

Asian-Oceanian Standard-Setters Group. (2010). Reasearch Paper: Financial Reporting Issues relating to Finance.

Retrieved

from http://www.aossg.org/docs/AOSSG_IF_WG-Research_Paper_11Oct2010.pdf

Asian-Oceanian Standard-Setters Group. (2011). AOSSG Survey: Accounting for Islamic Financial Transactions and $\quad$ Entities. $\quad$ Retrieved from http://www.aossg.org/docs/Publications/AOSSG_Survey_Report_2011_FINAL_CLEAN_29_12_2011.pdf

Atmeh, M., \& Ramadan, A. (2012). A critique on accounting for the mudarabah contract. Journal of Islamic Accounting and Business Research, 3(1), 7-19. http://dx.doi.org/10.1108/17590811211216032

Fatima, M. (2006). Differences and similarities between Ijara and conventional operating lease contracts. Market Forces, 1(4).

Kamali, M. A. (2007). A Shari'ah Analysis of Issues in Islamic Leasing. J.KAU: Islamic Econ., 20(1), 3-22. Retrieved from http://islamiccenter.kau.edu.sa/arabic/Magallah/Pdf/20_1/20-1_Kamali_05.pdf

Rosly, S. A. (2010). Shariah parameters reconsidered. International Journal of Islamic and Middle Eastern Finance and Management, 3(2), 132-146. http://dx.doi.org/10.1108/17538391011054372

Uddin, N. (2012). Comparative Analysis of Reporting Practices of Islamic Financial Institutions (IFIs). In: the 16th International Business Research Conference. Dubai, UAE. Retrieved from http://www.wbiconpro.com/110-Nazim.pdf

Usmani, M. T. (2003). Ijarah. Retrieved from http://www.accountancy.com.pk/docs/islam_Ijarah.pdf

\section{Notes}

Note 1. Usufruct is the right of enjoying all the advantages derivable from the use of something that belongs to another, as far as is compatible with the substance of the thing not being destroyed or injured (http://dictionary.reference.com/browse/usufruct)

Note 2. Rent is what the lessee is committed to pay as a consideration for the benefit enjoyed by him (AAOIFI, 2008, P. 267).

Note 3. On August, 2010, the International Accounting Standards Board (IASB) published an exposure draft ED/2010/9 Leases for comment only. In this draft, the classification of finance and operating lease is removed and a new accounting approach is proposed.

Note 4. Accounting and Auditing Organization for Islamic Financial Institutions (AAOIFI) was established in 1991 in Bahrain to provide a reliable platform for the accounting treatment of Shariah compliant contracts. The AAOIFI approach is to adopt the accounting concepts developed and used by conventional accounting, as long as these concepts do not contradict with Islamic principles. Hence, the role of AAIOFI is to fill the gap by developing Islamic accounting standards for Shariah compliant contracts as such standards are not available in conventional accounting (Atmeh and Ramadan, 2012).

Note 5. AAOIFI defines operating lease/Ijarah as contracts that do not end up with the transfer of ownership of leased assets to the lessee (AAOIFI, 2008, P. 277).

Note 6. Useful life is the time period over which this asset is expected to render services (AAOIFI, 2008, P. 277).

Note 7. In a fixed asset case, it may be assumed that AAOIFI followed the revaluation model stated in IAS 16, where the revaluation surplus should appear in the stockholder's equity section.

Note 8 . The fair rental value may be estimated yearly according to the market conditions. The aim of the example is to demonstrate the accounting treatment in general rather than discussing the measurement issues.

Note 9. Some studies classify this asset as a financial instrument (option) rather than an intangible asset (Kamali, 
2007)

Note 10. In case the Ijarah contract rescinded before the end of Ijarah term, this asset will be reclassified as receivable due from lessor.

Note 11. AAOIFI uses this type of contract (donation) extensively to imitate conventional products that meet Shariah requirements, e.g., the main difference between Islamic insurance and conventional insurance relies on the existence of a donation contract. It is worth mentioning though, that no sufficient research has been conducted in this area.

Note 12. For the sake of simplicity, yearly evaluation of these accounts are ignored, and consequently these accounts are assumed to be equal (refer to the example). 